\title{
Development of curd dishes for gluten-free nutrition
}

\author{
G.E. Rysmukhambetova ${ }^{1}$, E.N. Artemova ${ }^{2}$, K.E. Beloglazova ${ }^{1, *}$, and $Y$ u.V. Ushakova ${ }^{1}$ \\ ${ }^{1}$ Saratov State Agrarian University, Russian Federation \\ ${ }^{2}$ Oryol State University named after I.S. Turgenev, Russian Federation
}

\begin{abstract}
This work is devoted to expanding the range of dietary foods for people with celiac disease. In many countries, the number of alimentary-dependent diseases has been increasing, which is associated with disorders in the diet structure, lifestyle, genetic predispositions, etc. The increase in food intolerances and allergies in children and adolescents is considered to be a particularly alarming trend. The paper proposes replacing gluten-containing raw materials (wheat flour) with dietary fiber as a structure former in the technology of curd culinary products. The influence of dietary fibers of various nature (xanthan, guaran and food bamboo fiber) in the amount of $0.1-1.0 \%$ on the quality of curd soufflé and curd zrazy with raisins intended for gluten-free nutrition was studied. Organoleptic and physicochemical studies of the developed culinary products were carried out, and the nutritional and energy value was assessed. The prospect of using dietary fiber in the technology of culinary products from curd for gluten-free nutrition is substantiated.
\end{abstract}

\section{Introduction}

The development of food for personalized nutrition is one of the topical directions in the food industry according to the NTI concept (National Technological Initiative) until 2035. This is due to the fact that the design, production and sale of personalized and general, based on traditional raw materials and their substitutes, food products are in demand for the population in terms of the use of health-saving technologies, taking into account diseases, food allergies, types of professional activities, national traditions, etc. [1]

It should be borne in mind that it is required to expand the range of specialized food products, which must be free of certain ingredients due to medical indications. Examples are allergens (honey, citrus fruits, nuts, etc.) and food intolerance to any nutrients (casein, lactose, whey proteins, etc.). Celiac disease belongs to the alimentary-dependent diseases and consists in the progressive development of atrophy of the mucous membrane of the small intestine and the associated malabsorption syndrome.

The main components of gluten are prolamins (wheat gliadin, rye sekalin, barley hordein and oat avenin), which make up $5-50 \%$ of the total amount of protein, soluble in $60-80 \%$ ethanol solution, and glutelins soluble in 0.1-0.2 \% alkali solutions. By now, it has been proven that glutelins have toxic amino acid sequences identical to the peptides of

\footnotetext{
* Corresponding author : k.beloglazova@yandex.ru
} 
prolamins; therefore, usually only one common name (gluten) for toxic cereal proteins is used [2].

Although there are a number of gluten-free products on the current market, the demand for new modified gluten-free technologies is constantly growing due to consumer interest.

Traditionally, wheat and the product of its processing, flour, have been used as a source of energy in many countries, the consumption of which is prohibited for people with celiac disease (20\% of the world's population, according to the latest information [3]).

Existing industrial technologies make it possible to replace wheat flour only partially with other types of raw materials, some of which are gluten-free (oatmeal, rice flour, amaranth flour, etc.) In this case, a significant deterioration in the structural and mechanical properties of semi-finished products and subsequently the finished product's quality is possible. This happens due to the fact that non-traditional types of flour do not contain the required amount of gluten of the required quality. It is known that various improvers have been actively used now, which regulate the intensity of biochemical and colloidal processes, regulate acidity, and also improve structural and mechanical properties, which generally contribute to the long-term preservation of high-quality products [4]. Dietary fibers are widely used as food additives to improve the structural and mechanical properties of food products, especially flour and meat products [5]. There are almost no data in the literature on the use of dietary fiber in the technology of curd products.

The aim of this work was to develop a technology of curd dishes for gluten-free nutrition using the microbial polysaccharide xanthan, the vegetable polysaccharide guaran, and dietary bamboo fiber (DBF).

The objectives of our study included experimental confirmation of the advisability of using dietary fiber in the composition of culinary products made from curd; assessment of their influence on several complex indicators of the developed products from curd, including their food and energy value.

\section{Materials and research methods}

The objects of our research were culinary products made from curd "Curd souffle" and "Curd zrazy with raisins" [6].

In the work, we used food raw materials which correspond to the normative and technical documentation in force on the territory of the Russian Federation [7-12].

Guaran (Guarsar, India) and xanthan (Deosen, China) corresponding to the technical regulation (TR) CU 029/2012 [13] and bamboo fibers (Rutazel concentrate, J. Rettenmaier, Germany) [14] were considered as dietary fibers used in the production of our developed products.

The research methods used in the work for sampling and the assessment of organoleptic and physicochemical parameters, as well as the quantitative assessment of the main nutrients (fat, sugar, and moisture) corresponded to the standards [15-21].

The nutritional and energy value of curd dishes was estimated by the traditional calculation method based on tables of the chemical composition and calorie content of Russian food products [22].

\section{Research results}

In accordance with the goal, the possibility of replacing wheat flour as a gluten-containing raw material with dietary fibers of xanthan, guaran and bamboo fibers in the recipes "Curd soufflé" and "Zrazy from curd with raisins" was examined, considering them primary as structure formers. 
Curd is known to be rich in proteins, vitamins and minerals necessary for the human body and maintaining the normal functioning of all vital systems [23]. In turn, xanthan, guaran and bamboo fibers have structure-forming properties, are available and safe. Our choice of dishes was also based on the fact that they are common in the diet of not only adults, but also children.

To estimate the optimal amount of dietary fiber, ensuring the receipt of high-quality curd dishes, several compositions shown in Table 1 were adopted.

Table 1. Experiment matrix

\begin{tabular}{|c|c|c|c|c|c|c|c|c|c|c|}
\hline \multicolumn{11}{|c|}{ Compositions } \\
\hline \multirow[t]{2}{*}{ Control } & \multicolumn{10}{|c|}{ Polysaccharide concentration, \% } \\
\hline & 0.1 & 0.2 & 0.3 & 0.4 & 0.5 & 0.6 & 0.7 & 0.8 & 0.9 & 1.0 \\
\hline \multirow[t]{12}{*}{-} & \multicolumn{10}{|c|}{ Samples of "Curd soufflé" with xanthan } \\
\hline & 1.1 & 1.2 & 1.3 & 1.4 & 1.5 & 1.6 & 1.7 & 1.8 & 1.9 & 1.10 \\
\hline & \multicolumn{10}{|c|}{ Samples of "Curd soufflé" with guaran } \\
\hline & 2.1 & 2.2 & 2.3 & 2.4 & 2.5 & 2.6 & 2.7 & 2.8 & 2.9 & 2.10 \\
\hline & \multicolumn{10}{|c|}{ Samples of "Curd Souffle" with DBF } \\
\hline & 3.1 & 3.2 & 3.3 & 3.4 & 3.5 & 3.6 & 3.7 & 3.8 & 3.9 & 3.10 \\
\hline & \multicolumn{10}{|c|}{ Samples of "Curd zrazy with raisins" with xanthan } \\
\hline & 4.1 & 4.2 & 4.3 & 4.4 & 4.5 & 4.6 & 4.7 & 4.8 & 4.9 & 4.10 \\
\hline & \multicolumn{10}{|c|}{ Samples of "Curd zrazy with raisins" with guaran } \\
\hline & 5.1 & 5.2 & 5.3 & 5.4 & 5.5 & 5.6 & 5.7 & 5.8 & 5.9 & 5.10 \\
\hline & \multicolumn{10}{|c|}{ Samples of "Curd zrazy with raisins" with DBF } \\
\hline & 6.1 & 6.2 & 6.3 & 6.4 & 6.5 & 6.6 & 6.7 & 6.8 & 6.9 & 6.10 \\
\hline
\end{tabular}

According to the data obtained, the dietary fibers selected for the preparation of curd soufflé had a different effect on its consumer properties.

During the preparation of the samples, it was noted that at a higher xanthan concentration, the soufflé mass became more viscous during mixing, whilst some oil was separated at a lower concentration. It was also noted that xanthan was poorly soluble in water (the optimal temperature for xanthan dissolution is $25 \div 70^{\circ} \mathrm{C}$ ), therefore, clots were formed, thereby increasing the preparation time. As a result of comparing the organoleptic properties of the samples, it was found that the sample with xanthan at a concentration of $0.7 \%$ had relatively high characteristics in relation to other experimental samples with this food additive. However, although having a pleasant smell and taste, the consistency of both the semi-finished and finished products did not meet the requirements for soufflé. After baking, the soufflé was dense and did not have a pronounced characteristic porosity.

The addition of guaran in the selected concentrations also had a different effect on the organoleptic properties of soufflé. E.g., the mass of soufflé with a high guaran content (from 0.5 to $1.0 \%$ ) became more viscous at the kneading stage, and the products after baking were dense and had no appropriate texture. The best organoleptic properties were possessed by the sample with the amount of guaran of $0.3 \%$, and both the semi-finished and baked products had a homogeneous structure, corresponding taste and aroma.

During the preparation of samples of "Curd soufflé" with food bamboo fibers, it was noted that at a concentration of $0.4 \%$ or higher, the soufflé mass became more viscous during kneading and visibly thickened after heat treatment. This somewhat reduced the taste perception of such a soufflé and made its consistency uneven. Samples with lower concentrations of dietary bamboo fiber (from 0.1 to $0.2 \%$ ) had a delicate aftertaste as compared to the control. The manifestation of a pronounced curd smell in all experimental samples compared to the control was a positive effect of the bamboo fiber introduction. The best organoleptic characteristics were exhibited by the sample with $0.2 \%$ food bamboo 
fibers. This product had a ruddy crust on its surface, a uniform consistency, a pronounced curd smell and a delicate aftertaste.

When producing curd zrazy with raisins, it was noted that the samples with xanthan from 0.1 to $0.4 \%$ did not have the required shape stability, and those from 0.5 to $1 \%$ had an unpleasant astringent texture and aftertaste. The mass fraction of xanthan $0.5 \%$ was found to be optimal for preparing zrazy from the given concentration range. However, low organoleptic characteristics excluded this product from further research.

The best organoleptic properties of curd zrazy with raisins were observed with the addition of guaran in an amount of $0.4 \%$. It was noted that with concentrations from $0.5 \%$ to $1.0 \%$, the finished products had an unpleasant aftertaste and an astringent texture, dense after heat treatment. With concentrations from $0.1 \%$ to $0.3 \%$, the texture of the product was crumbly, which is undesirable for this product. As a result, zrazy with a guaran concentration of $0.4 \%$ received the highest rating.

Dietary bamboo fiber in the amount of $0.1-0.4 \%$ made the curd mass viscous and spreadable, which had increased stickiness and was poorly shaped. The taste of the finished product was moderately sweet and sour; its consistency was heterogeneous, crumbly, with cracks on the surface. At higher concentrations, from $0.5 \%$ to $1.0 \%$, the consistency of the curd dough thickened and the semi-finished products were easily shaped. However, the finished zrazy had not only sweet and sour, but also astringent taste at the highest concentrations of bamboo fibers. The consistency of the products was moist, homogeneous, with no cracks observed on the surface. The best organoleptic properties were exhibited by curd zrazy with bamboo fibers in the amount of $0.6 \%$.

In general, our organoleptic evaluation has shown that the use of guaran and food bamboo fibers in experimentally substantiated concentrations, in contrast to xanthan, makes it possible to obtain curd culinary products with a high organoleptic rating.

The physicochemical indicators (dry matter, fat, sugar, total [titratable] acidity) of the organoleptically best samples of curd culinary products with dietary fiber, along with control samples and the initial basic raw material (curd), are presented in Table 2.

Table 2. Physicochemical indicators of the studied samples of curd culinary products

\begin{tabular}{|c|c|c|c|c|c|c|c|c|}
\hline \multirow[b]{2}{*}{ Indicator } & \multirow{2}{*}{$\begin{array}{c}\text { Curd } \\
\text { GOST } \\
31453- \\
2013\end{array}$} & \multicolumn{3}{|c|}{ Curd soufflé } & \multicolumn{3}{|c|}{ Curd zrazy with raisins } & \multirow{2}{*}{$\begin{array}{l}\text { Meth } \\
\text { od } \\
\text { error, } \\
\text { abs. }\end{array}$} \\
\hline & & $\begin{array}{c}\text { contro } \\
1\end{array}$ & $\begin{array}{c}\text { with } \\
0.3 \% \\
\text { guaran }\end{array}$ & $\begin{array}{l}\text { with } 0.2 \\
\% \text { DBF }\end{array}$ & control & $\begin{array}{c}\text { with } \\
0.4 \% \\
\text { guaran }\end{array}$ & $\begin{array}{l}\text { with } \\
0.6 \% \\
\text { DBF }\end{array}$ & \\
\hline $\begin{array}{l}\text { Moisture } \\
\text { content, \% }\end{array}$ & $\begin{array}{c}\text { No more } \\
\text { than } 73\end{array}$ & 63.9 & 69.0 & 67.1 & 42.9 & 50.3 & 45.0 & 0.3 \\
\hline $\begin{array}{l}\text { Fat mass } \\
\text { fraction, \% }\end{array}$ & $\begin{array}{l}\text { No more } \\
\text { than } 9.5\end{array}$ & 9.2 & 9.3 & 9.6 & 9.4 & 9.1 & 9.6 & 0.5 \\
\hline $\begin{array}{l}\text { Mass fraction } \\
\text { of total sugar, } \\
\text { expressed in } \\
\text { invert sugar, } \\
\%\end{array}$ & \multirow[t]{2}{*}{ * } & 10.6 & 11.1 & 10.4 & 21.2 & 27.5 & 28.6 & \multirow[t]{2}{*}{0.7} \\
\hline $\begin{array}{l}\text { Mass fraction } \\
\text { of total sugar, } \\
\text { expressed in } \\
\text { sucrose, \% }\end{array}$ & & 10.1 & 10.5 & 9.9 & 20.2 & 26.1 & 27.2 & \\
\hline $\begin{array}{l}\text { Total (titrata- } \\
\text { ble) } \\
\text { acidity, }{ }^{\circ} \mathrm{T}\end{array}$ & $\begin{array}{l}\text { No more } \\
\text { than } 220\end{array}$ & 91.0 & 95.0 & 115.0 & 116.0 & 124.0 & 118.0 & 3.5 \\
\hline
\end{tabular}

Note $-(*)$ this indicator is not specified in GOST 31453-2013 
According to our experimental data obtained, the addition of guaran increased the moisture content of the curd soufflé and curd zrazy with raisins by $5.1 \%$ and $7.4 \%$, respectively, compared to the control. Dietary bamboo fibers increased the moisture content of the soufflé and zrazy by $3.2 \%$ and $2.1 \%$. relative to the control, respectively. Obviously, the data/findings obtained are associated with the high water-retention capacity of the dietary fiber used. The dietary fiber used did not significantly affect the fat content and mass fraction of total sugar, and the results are within the margin of error of the used research methods.

At the same time, the mass fraction of total sugar, expressed in invert sugar and sucrose, in zrazy with guaran and with DBF increased by $6.3 \%$ and $5.9 \%$, and by $7.4 \%$ and $7 \%$, respectively.

The total (titratable) acidity of the samples from curd with guaran and DBF was higher in the soufflé by 4.0 and $24.0^{\circ} \mathrm{T}$, and in the zrazy - by 8 and $3.0^{\circ} \mathrm{T}$ compared to the control, respectively. The increased acidity is caused by the properties of the dietary fibers used and contributes to the formation of the taste of the finished product.

The nutritional and energy value of our studied samples of curd culinary products are presented in Table 3.

Table 3. Nutritional and energy value of the studied samples of curd culinary products per $100 \mathrm{~g}$

\begin{tabular}{|l|c|c|c|c|c|c|}
\hline \multirow{2}{*}{ Indicator } & \multicolumn{3}{|c|}{ "Curd soufflé" } & \multicolumn{3}{c|}{ "Curd zrazy with raisins" } \\
\cline { 2 - 7 } & Control & $\begin{array}{c}\text { with } 0.3 \% \\
\text { guaran }\end{array}$ & $\begin{array}{c}\text { with } \\
0.2 \% \\
\text { DBF }\end{array}$ & Control & $\begin{array}{c}\text { with } 0.4 \% \\
\text { guaran }\end{array}$ & $\begin{array}{c}\text { with } \\
0.6 \% \\
\text { DBF }\end{array}$ \\
\hline Proteins, g & 12.42 & 12.52 & 12.53 & 12.00 & 12.12 & 12.1 \\
\hline Fat, g & 7.69 & 8.10 & 8.11 & 8.57 & 9.28 & 9.26 \\
\hline Carbohydrates, g & 12.25 & 8.82 & 8.80 & 24.66 & 20.59 & 20.51 \\
\hline Vitamin A, $\mu \mathrm{g}$ & 50.95 & 54.15 & 54.15 & 60.62 & 66.55 & 66.42 \\
\hline$\beta$-carotene, $\mu \mathrm{g}$ & 25.14 & 26.72 & 26.72 & 35.32 & 38.78 & 38.70 \\
\hline Vitamin B1, mg & 0.04 & 0.03 & 0.03 & 0.06 & 0.05 & 0.05 \\
\hline Vitamin B2, mg & 0.20 & 0.21 & 0.21 & 0.18 & 0.20 & 0.20 \\
\hline Vitamin PP, mg & 0.34 & 0.29 & 0.29 & 0.41 & 0.33 & 0.33 \\
\hline Vitamin C, mg & 0.22 & 0.23 & 0.23 & 0.14 & 0.16 & 0.16 \\
\hline Na, mg & 40.34 & 42.73 & 42.68 & 42.74 & 52.63 & 52.46 \\
\hline K, mg & 106.97 & 106.10 & 105.97 & 106.12 & 209.21 & 208.63 \\
\hline Ca, mg & 117.54 & 123.83 & 123.83 & 123.83 & 111.77 & 111.56 \\
\hline Mg, mg & 16.29 & 16.38 & 16.38 & 16.38 & 19.83 & 19.80 \\
\hline P, mg & 156.22 & 160.71 & 160.70 & 160.71 & 163.37 & 163.04 \\
\hline Fe, mg & 0.46 & 0.41 & 0.41 & 0.41 & 0.93 & 0.93 \\
\hline EV, kcal & 174.48 & 164.28 & 164.30 & 233.21 & 223.29 & 222.69 \\
\hline
\end{tabular}

Our developed curd products differ little from the control in terms of protein and fat content. The fraction of fat slightly increases, which is obviously associated with the fatholding capacity of dietary fiber.

At the same time, the amount of carbohydrates in soufflé and zrazy decreased significantly (by $28 \%$ and $16 \%$, respectively). This, in turn, influenced the decrease in its energy value by $5.86 \%$ and $4.29 \%$, respectively. Due to changes in the component composition of curd zrazy, there was a slight decrease in the content of vitamins and minerals (by $9.24 \%$ on average). At the same time, this product can be recommended for use as a functional product in terms of the contents of dietary fiber, calcium, magnesium, phosphorus and vitamin B2 (an increased content of the vitamin-mineral complex). 


\section{Conclusions}

The influence of dietary fiber on the organoleptic and physicochemical parameters of curd culinary products was studied, its nutritional and energy value was estimated.

The expediency of using guaran and dietary bamboo fibers in the composition of curd soufflé and curd zrazy with raisins was experimentally confirmed, the amount of the considered dietary fiber in the formulations was substantiated. It has been proven that the use of xanthan in the technology of the studied curd culinary products is not desirable from an organoleptic point of view.

It has been proven that the complete replacement of gluten-containing raw materials (wheat flour) with dietary fiber in the recipes of curd soufflé and curd zrazy with raisins did not significantly affect their nutritional and energy value. The developed curd culinary products expand the range of dietary food products for people with celiac disease.

\section{References}

1. National Technological Initiative: [Electronic resource]. - Access mode.. URL https://www.nti2035.ru.

2. Gupta, A. Celiac disease in type 1 diabetes mellitus: What are the implications of early diagnosis? / A. Gupta // Indian J. Med. Res. - 2018. - Vol. 147, N 2. - P. 207-208.

3. Kozlova, E.I. Analysis of current trends in the field of food production for people suffering from celiac disease / E.I. Kozlova // Education and Science without Borders: Fundamental and Applied Research. - 2018. - No. 8. - P. 194-198.

4. Boytsova, Yu.S. Specialized food products in the modern world / Yu.S. Boytsova // International Journal of Humanities and Natural Sciences. - 2020. - No. 3-1 (42). - P. 51-54.

5. Shelepina, N.V. Use of various structure-formers in food production / N.V. Shelepina, N.E. Huseynova // Scientific notes of Oryol GIET. - 2010. - No. 2. - P. 429-431.

6. Collection of recipes for dietary food products for public catering enterprises / Ed. M.P. Mogilny, V.A. Tutelyan. - Moscow: DeLi plus, 2013. - 808 p.

7. GOST 6882-88 Dried grapes. Technical conditions. - Intro. 1989-01-01. Moscow: Standartinform, 2009. -8 p.

8. GOST 31450-2013 Drinking milk. Technical conditions. - Intro. 2014-07-01. Moscow: Standartinform, 2019. - 8 p.

9. GOST 26574-2017 Wheat flour. Specifications (with Amendment). - Intro. 2017-0101. Moscow: Standartinform, 2017. - 15 p.

10. GOST 33222-2015 White sugar. Technical conditions. Intro. 2016-07-01. Moscow:Standartinform, 2019. - 16 p.

11. GOST 31453-2013 Curd. Technical conditions. - Intro. 2014-07-01. Moscow: Standartinform, 2013. -8 p.

12. GOST 31654-2012 Edible chicken eggs. Technical conditions. - Intro. 2014-01-01. Moscow: Standartinform, 2013. - 8 p.

13. TR CU 029/2012 Technical Regulations of the Customs Union "Safety requirements for food additives, flavorings and technological aids" (as amended on September 18, 2014). - Intro. 2012-01-01. Moscow: Standartinform, 2012. - 8 p.

14. Rutazel bamboo fibers (cellulose concentrate): [Electronic resource]. - Access mode URL: https://ayurvedasaratov.ru/goods/Rutacel-bambukovye-volokna-koncentratkletchatki-97-200-g.

15. GOST 3626-73 Milk and dairy products. Methods for anslysis of moisture and dry matter. - Intro. 1974-06-30. Moscow: Standartinform, 2009. - 51p. 
16. GOST 3622-68 Milk and dairy products. Sampling and sample preparation for testing. - Intro. 1969-06-30. Moscow: Standartinform, 2009. - 44 p.

17. GOST 26809-86 Milk and dairy products. Acceptance rules, sampling methods and sample preparation for analysis. - Intro. 1987-01-01. Moscow: Standartinform, 2009. $9 \mathrm{p}$.

18. GOST 31986-2012 Catering services. Method of organoleptic assessment of the quality of public catering products. - Intro. 2015-01-01. Moscow: Standartinform, 2014. $11 \mathrm{p}$.

19. GOST R 54669-2011 Milk and milk processing products. Methods for the analysis of acidity. - Intro. 2013-01-01. Moscow: Standartinform, 2012. - 10 p.

20. GOST R 54607.5 - 2015 Public catering services. Methods for laboratory control of public catering products. Part 5. Methods for fat analysis. - Intro. 2016-06-01. Moscow: Standartinform, 2016. - 12 p.

21. GOST R 54607.6 - 2015 Public catering services. Methods for laboratory control of public catering products. Part 6. Methods for sugar analysis. - Intro. 2016-06-01. Moscow: Standartinform, 2016. - 26 p.

22. Tables of the chemical composition and calorie content of Russian food products: Handbook / Ed. Prof. I.M. Skurikhin. - Moscow: DeLiprint, 2007. - 276 p.

23. Morozova, L.N. Features of the technology of curd dishes for therapeutic and prophylactic purposes / L.N. Morozova, A.V. Il'in // Actual problems of public catering. Proc. of the All-Russian scientific-practical conference. - 2020. - P. 117-122. 